are reported. In these cases the action is slow, so that for speedy relief other remedies must he resorted to. It can be stated, however, that it can he administered for neuralgias and hahitnal headaches for a long time without injury to the stomach.-Correxpondenzblatt für Schweizer Aerzle, 1893, No. 18 , S. 609 .

\title{
The Treatarent of Diarrega.
}

Dr. Alors PICk helieves that opium plays a great role in the treatment. Next come the hismuth preparations, and especially the salicylate, at first in large doses in order that the powder may form a protective coating to tha alimentary canal. In stomach disturhances, alum can ha noed with advantage. Tannin is seldom employed on account of its disordering the stomach. Sometimes the iron preparations are useful. The use of Glauher salts, as recommended hy Trousseau, may he hegun hy the use of two and one-halfdrachm doses, dissolved in water, and continued for one or two weeks in onebalf the dose. In many chronic cases a preliminary emptying of tha howels, followed hy styptic treatment, is necessary. In diarrhoea secondary to constipation, to strengthen the intestinal muscles, massage, electricity, and cold. water cures may be indicated. Io nerrous diarrhoen (of women), the electrical treatment with galvanism, or a strong faradic curreot, is voluahle io diminishing the increased excitability of the intestines.-Ceniralblall fur die gesammle Therapie, 1893, Heft 24, 5. 578 .

\section{The Abjorition of Sahcylo heid by THE SkiN.}

DB. BOURGET reports nineteen cases of inflammatory rheumotism treated exclusively by exteroal use of aslicylic ocid, ood he coocludes that it is ohsorhed io a sufficiently large quantity from the skio for s ropid and perhops for a more rapid cure thoo when given hy the mouth. It suppresses the pain with surprising rapidity, dimiuishes the swelling, and the fever graduolly falls. The ointment containing the drug is opplied orer the circumference of the affected joiots, and the limh is cotered witl o flannel bandage. The urine for the trenty-four hours was carefully collected and examined to determine the presence of the remedy. The following conclusinns are presented : 1 . The ahsorption of the aslicylic acid by the skin is rapid and marked. The skin of the young ahsorhs hetter than that of old suljects, of hlondes hetter than hrunettes. 2. The rapidity and intensity of ahsorption depends upon the vehicle in which it is dissolved. Fatty hodies are the nnly ones which nllow the greatest penetration, whila with vaselin or glycerin it is ahsent or sliglit. 3. The treatment of acute articular rheumatism witb a terehinthinated salicylic ointment is strongly recommended. 4. This ointment is less efficacious in other forms of rheumatism, hut it may he of assistance in the treatment of these affections hy massage. 5. It has no value in gonorrhoal rheumatism. The formnla recommended is: Salicylic acid, essence of turpentine and Iannlin, of each ten parts, of lard one hundred parts. The amount of salicylic acid which is eliminated hy way of the urine in twenty-four hours raries from three to nine grains.- Revue Nfedicale de la Suisse Romande, 1893, No. 9, p. 567. 


\section{Salipyris in Amexorthces.}

Dr. Horatio R. Bigelow reports an iastaace where, after two fifteengrain doses with an interval of two hours, a facial a euralgia disappeared aod meastroation was estahlished. Zurbelle has found that this renedy is more efficieat than ergot, but poiats oot that it is contra-iodicated is certain pathological chaoges of the uterus. Many aeuralgic womeo are deficient meastruators and menstruate paiofully. In ndmioistering to the disensed aervous centres, or to an impaired eirculation, you restore the mootbly functioo to normal. Too mach hlood, uahealthy hlood, anamia, predispose to aeoralgia, and disturb the meastrual fuactioa. A rheumatic, nenralgic, gnuty, or malarious individual never performs these fuoctions satisfactorily. The uterus is quite rarely at fault; the impaired aerve nutritino must he atteaded to. For the same renson that salipyrio will cure oeuralgia, it will also cure amenorrhcea; it addresses itself to nutrition. The treatment by salipyrin was contioued for two weeks, in the same dose, given three times daily. The sleep wns uodisturhed, appetite was improved, and the relief of hoth amenorrhea aod the nenraligia was complete. - Notes on New Remedics, 1893, No. 5, p. 66.

\section{The Sepative Actrox of Dobotslye is CoNinded Doses ix IxsaxITY.}

Dr. E. Marandon de Montyed, in his service nt ville-Erraud, has administered this remedy as a sedntive ia coatinued doses during the day to thirty-five patients. The results have heen marvellous, nnd in cases of ngitation it ofteo changes violent excitement iato $n$ perfect tranguillity. Unlike hyosciae, it does not paralyze the voluotary muscles, nor does it, like somaal, a arcotize the patient. Its nction is not immedinte, for it may not he complete until the secood, sometimes until the third day. When its effect has been ohtuioed it persists quite regularly, so that ordisarily the patients do not experience regularly good and had days. Further, it frequeatly lappeas tbut the improvemeot mny coatinue for sereral days after the cessa. tios of the mediciae, and a period of $\mathrm{calm}$, more or less prolonged, may he estahlished. An important fact is its ndmiaistratioa is, that when ooce a tolerasce is estahlished the patients ordinarily fail to be iofueoced hy the drug, so matter how large the dnse, and the marvellous sedation of the first days cannot again he obtajoed. The dose employed has heen from one-thirtysecond to ooe-sixth of a graia, in two equal portioss at aioe in the morning and at three in the afternoos, the patieats receiviag their food at seven and elereo in the moroiog and at five ia the afternoon. The remedy appears to have an unfavorable action upoa nutrition.-Arehives de Neurologie, 1893, No. 79, p. 211.

\section{The Action of Trioxal.}

Dr. Oscar Concatz reports the regalt nf the use of this drug as a hypnotic io sixty-six cases of insanity, generally ia fifteeo- to thirty-graia doses. It does not ioterfere with either the circalation aor the respiration, and the digestion is a ot impaired. Albumia is not fonnd in the urine, sor are hlood- 
corpnscles nor evidence of blood-coloring matter present. The condition of the blood, even after several weeks' nse of the remedy is normal. Although it is free from injurious after-effects, even after long-continued use, it is not an nbsolutely relinble remedy.-Berliner klinische Wochensehrift, 1893, No. 40, S. 966 .

\section{The Untowarn Fffects of ANTipyrin, Acetanilide, AND Phenacetris.}

Dr. D. R. Paterson, from a study of the reports of twenty-ive phyaiciang to the South Wales Branch of the British Mredical Association, presents the following conclusions: Anlipyrin. Large doses depress the nerrous aystem, positive results varying from an unpleassant diaphoresis to severe collapse. Most of them may he referred to the action on the nersons system, producing exhaustion and collapse following the fall of temperature; nnd tbere may he disturhance of the circulntion for the same resson, or secondnrily from the effect on tbe hlood-corpuscles and the production of metbremoglobinæmia. Other aymptoms, such as afections of the skin nnd pronounced psychical disturhance, are more rare. Minor degrees of depression are represented by unpleasant diaphoresis, which may be so profuse as to prostrate the pstient temporarily. Continued use of even smsil doses not in frequently leads to a condition in which the patient complnlns of having lost his energy, is disinclined to exert himself and becomes depressed mentally; in short, there is established nn nntipyrin habit. Blueness of the lipa and face is one of the concurrent untoward effects, varying from that which ls first perceptible to a deep cyanosis with profound collapse. Acelanilide has been rery early. nbandoned by mnny practitioners because of the frequent onset of symptoms of intorication nnd the nlarming appearance which they sometimes aqsume. The consensus of opinion is that aymptoms of depresgion and collnpse are more readily produced and are more marked than with the other drug; and this may he explained by the fall of temperature heing grenter and more rapid. Srost of the reports mention cyan osis, nnd to a greater degree than nfter nntipyrin. Angmin may be indnced by its continued use and become n grave condition. Phenacetin is more free from ill effects than either of the other two substances. Its depressant action on the nerrous system and heart is manifest only when very large doses nre given, smull amounts, tsken frequently, being borne without ill effects. It is not, however ahsolutely free from unplessant conseqnences. Eisenhart reports a case which presented the symptoms of palpitation, oppression, dulness of hearing, then nausen and vomiting. With the onset of gicleness all traces of intosication vanished, and the patient felt well. Skin eruptions, chiefly urticarial, are said to be met with.-The Practitioner, 1893, No. 304, p. 241.

\section{The action of Strontiour upos Renal Pabenchyara.}

Dott. Cesare Falcone notes the ohservation of Malbec, that the Lidneys of a dog which hnd received the nitrate for nearly a month did not show any anatomical changes, although the liver contained a notable quantity of strontium. On the otber hand, a dog which had taken the neutral tartrate for 
more then e hundred deys, on necropsy was ghown to have n certain degree of reool congestion. Experiments with the lactate (dogs) show thet there is e gradual hut cleerly merked diminution in the emount of urine passed. On the thirteenth day e trace of albumin appesred, end ten deys leter the amount could he readily determined, end the increase was continued until e large percen tage was reeched. The nrohilin steodily incressed in amount Dntil, et the fourteenth dey, there was a troe urohilinuria. Microscopical exemination of the urine showed gronnlor end hyeline casts end red hlood-glohnles. All of the fects point to en irritative process going on in the kidneys. Careful microscopical exeminetion of the kidneys, after removel hy necropsy, demonstrates heyond douht thet this remedy in long-continued edministration produces an initial form of nephritis._La Rijorma Medica, 1893, No. 205, p. 651.

\section{The Treatarest of Secondary Syphilides.}

Dr. AlFRED Foundier helieves that mexcury is the specific par excellence in the treatment of these conditions. On the contrary, potassium iodide exercises an iofuence infinitely less potent. Of the mercuriels he prefers, as most certain and efficacious, the suhlimate and the protiodide; the former helng especially reserved for tertinry menifestations, while the protiodide is hetter adepted for the conditions under discnssion. The dose should he average ones, and indeed active, as one and a half grains for a man, a guarter of a grain less for $\theta$ woman. Although in these conditions choice cen be made hetween exclusively general apd local treatment, reliance should be pleced chiefly upon the former, although both nre useful. The general trentment is directed not only to the lesion but to the disease as well; it for the present cures and for tho future is a eafeguerd. If the general treatment alone suffices it is useless to impose upon the patient the external treatment. If in certaio forms the internal treetment is impotent to cure mpidly, then exlernal methods can he resorted to for relief, end to destroy at the same time the active centres of contagion.-Revue generale de Clinigue et de Therrapeutique, 1893, No. 35, p. 545.

\section{The Compabative action of Iodoforar dPon the Staphylococcts AND UPON THE BLOOD CORPUSCLES.}

DR. E. MAUREL has ettempted to reconcile the contradictory views held hy hiologists end cliniciens coocerning iodoform. It was found that the drug is not poisooous for leucocytes, hut, on the contrary, their activity is increased in a monner proportional to the dose employed. But at the seme time there is the some ection npon them as in febrile temperotures, e compensation hetwcen the activity and the longevity of the lencocytes-one can only increase et the expense of the other. Even in large doses the drug is without ection upon the red hlood-corpuscles. So far as the drug ects upon the staphylococcus, the conclusion which has heen reached by many other experimenters is-now confirmed thet it does not seasihly modify the reproductivity of the staphylococcus. When, st the same time, hoth the stophylococcus end the hlood corpuscles are pleced under the influence of iodoform, it has heen found: 1. Thet it ettenuetes the virulence of the staphylococcus. 2. The 